\title{
ANALISIS SIKAP PENILAIAN PASIEN TENTANG JASA PELAYANAN KESEHATAN
}

\author{
Andri Purnamawati, S.E., M.M. \\ Akademi Manajemen Administrasi “Dharmala”
}

\begin{abstract}
The study, entitled "Analysis of Patients About Attitude Assessment in Health Care Services Medical Center Health Care and Rehabilitation Center (PPKR) BSMI Prambanan Klaten" which aims to determine how attitudes outpatient assessment of health services provided by the Center for Health Services and Medical Center Rehabilitation (PPKR) BSMI Prambanan Klaten that includes, facilities, workforce and location.

In this study, researchers used a test tool attidude towar object or model of Fishbein attitude to answer the hypothesis. The hypothesis that the attitude of the patient assessment of health care services that includes, facilities, workforce and location in the Medical Center Health Care and Rehabilitation Center (PPKR) BSMI Prambanan Klaten is positive, it is true and acceptable. Because after tested the hypothesis is proven, based on the patient's attitude about the assessment interval services Polyclinics Health Care and Rehabilitation Center (PPKR) BSMI Prambanan Klaten covering factors, facilities, workforce and location of 64.44 and enter the positive interval is $54.78<x$ $<67.66$, mean attitude positive patient assessment of services provided Polyclinics Health Care and Rehabilitation Center (PPKR) BSMI Prambanan Klaten.
\end{abstract}

Keywords: Attitudes Assessment Patients and Health Care Services (Services, Labor, Facilities and Location)

\section{PENDAHULUAN}

Dalam rangka mewujudkan pelayanan kesehatan yang optimal bagi masyarakat, sudah tentu diperlukan suatu pelayanan yang bersifat terpadu dan profesional dari para profesi penyedia jasa pelayanan kesehatan. Seperti yang kita ketahui, saat ini persaingan pelayanan kesehatan semakin meningkat, hal ini dapat kita lihat dari banyak munculnya fasilitas kesehatan mulai dari rumah sakit, apotek, balai pengobatan atau klinik, serta fasilitas kesehatan lainnya yang menawarkan jasa pelayanan kesehatan baik dari pihak pemerintah maupun dari pihak swasta.

Istilah perilaku erat hubungannya dengan obyek studi yang diarahkan pada masalah manusia. Dibidang studi pemasaran, konsep perilaku konsumen secara terus-menerus dikembangkan dengan berbagai pendekatan. Perilaku konsumen adalah tindakan langsung yang terlibat dalam mendapatkan, 
menghabiskan, mengkonsumsi, dan menghabiskan produk atau jasa, temasuk keputusan yang mendahului dan menyusul tindakan.

Untuk memahami konsumen dan mengembangkan startegi pemasaran yang tepat kita harus memahami apa yang mereka pikirkan (kognisi) dan yang mereka rasakan (pengaruh), apa yang mereka lakukan (perilaku) dan apa serta dimana (kejadian di sekitar) yang mempengaruhi serta dipengaruhi oleh apa yang dipikirkan, dirasa dan dilakukan oleh konsumen (Nugroho, 2010: 03).

Adanya hubungan yang erat antara sikap dan perilaku konsumen, inilah yang menjadikan sikap dipandang penting. Berbagai upaya dilakukan oleh pemasar untuk mengembangkan sikap positif, baik terhadap merk, produk, maupun terhadap perusahaan. Berbagai program komunikasi pemasaran didesain semenarik mungkin untuk mengembangkan sikap positif serta mengubah sikap yang netral maupun negatif ke arah sikap positif (Suryani, 2012:160).

Untuk dapat menghadapi segala bentuk persaingan di masa yang akan datang, penyedia pelayanan kesehatan dituntut untuk dapat memberikan pelayanan kesehatan yang bersifat terpadu, profesional, serta mengetahui apa yang menjadi kebutuhan dan keinginan masyarakat. Untuk itu penyedia jasa pelayanan kesehatan, dituntut untuk dapat menerapkan manajemen kualitas dalam pelayanan, sehingga kepuasan pasien atas pelayanan jasa yang diberikan, dapat menciptakan persepsi atau image yang baik bagi institusi pelayanan kesehatan tersebut.

Untuk memenangkan persaingan penyedia jasa pelayanan kesehatan harus mampu memberikan kepuasan kepada konsumen atau pasien, misalnya dengan memberikan kualitas pelayanan yang baik, biaya yang sepadan, dan pelayanan yang lebih baik dari penyedia jasa pelayanan kesehatan lainya.

Kualitas pelayanan dan kepuasan pelanggan menjadi indikator keberhasilan penyelenggaraan jasa pelayanan kesehatan. Oleh sebab itu tercapainya mutu pelayanan kesehatan dan kepuasan konsumen yang baik memerlukan upaya yang sungguh-sungguh dari penyelenggaraan jasa pelayanan kesehatan.

Kualitas pelayanan yang baik tidak cukup hanya dicapai saja, tetapi juga harus tetap dipelihara dan dipertahankan (quality assurance) mengingat adanya pergeseran kebutuhan, harapan dan keinginan dari pelanggan maupun dari berbagai pihak-pihak yang berkepentingan dengan kesehatan. Oleh karena itu pelayanan kesehatan, seharusnya merupakan suatu kegiatan yang berkelanjutan atau dapat dilakukan 
secara terus menerus, yang senantiasa akan meningkatkan kualitas pelayanan dan dapat memberikan masukan dan solusi terhadap masalah-masalah pelayanan dengan instansi yang terkait.

Klinik pratama adalah klinik yang menyelenggarakan pelayanan medik dasar. Sedangkan Klinik utama adalah klinik yang menyelenggarakan pelayanan medik spesialistik atau pelayanan medik dasar dan spesialistik. Sifat pelayanan kesehatan yang diselenggarakan bisa berupa rawat jalan, one day care, rawat inap dan atau home care.

Untuk itu klinik sebagai salah satu penyediajasa pelayanan kesehatan masayarakat harus mampu meningkatkan kualitasnya, baik dari segi pelayanan, tenaga kerja yang handal, lokasi yang strategis, serta fasilitas pendukung agar mampu memberikan kepuasan kepada para konsumennya, karena ada kecenderungan dari sikap masyarakat untuk menentukan alternatif dalam memilih penyedia jasa kesehatan lainnya.

\section{LANDASAN TEORI}

\section{A. Pengertian Pemasaran}

Inti dari pemasaran (marketing) adalah mengidentifikasi dan memenuhi kebutuhan manusia dan sosial. Salah satu definisi yang baik dan singkat dari pemasaran adalah "memenuhi kebutuhan dengan cara yang menguntungkan". American Marketing Association (AMA) menawarkan definisi formal berikut : pemasaran adalah suatu fungsi organisasi dan serangkaian proses untuk menciptakan, mengkomunikasikan, dan memberikan nilai kepada pelanggan dan untuk mengelola hubungan pelanggan dengan cara yang menguntungkan organisasi dan pemangku kepentingannya.

\section{B. Konsep Pemasaran}

1. Pengertian Konsep Pemasaran

Perusahaan yang sudah mulai mengenal bahwa pemasaran merupakan faktor penting untuk mencapai sukses usahanya, akan mengetahui adanya cara dan falsafah baru disebut konsep pemasaran (marketing concept). Sebagai falsafah bisnis, konsep pemasaran bertujuan memberikan kepuasan terhadap keinginan dan kebutuhan konsumen atau berorientasi pada konsumen (consumer oriented). Jadi secara defisit dapatlah dikatakan bahwa konsep pemasaran adalah sebuah falsafah bisnis yang menyatakan bahwa pemuasan kebutuhan konsumen merupakan syarat ekonomi dan sosial bagi kelangsungan hidup perusahaan (Swastha Basu, 2012 : 6). Tiga unsur pokok pemasaran (Swastha Basu, $2012: 6-8)$.

a. Orientasi Pada Konsumen

Perusahaan yang benar-benar ingin memperhatikan konsep harus : 
1) Menentukan kebutuhan pokok ( basic needs) dari pembelian yang dilayani dan di penuhi.

2) Menentukan kelompok pembeli yang dijadikan sasaran penjualan.

3) Menentukan produk dan program pemasarannya.

4) Mengadakan penelitian pada konsumen, untuk mengukur, menilai, dan menafsirkan keinginan sikap serta perilaku mereka.

5) Menentukan dan melaksanakan strategi yang paling baik.

b. Penyusunan Kegiatan Pemasaran Secara Integral (Integrated Marketing).

Pengintegrasian kegiatan pemasaran berarti setiap orang dan setiap bagian dalam perusahaan turut berkecimpung dalam satu usaha yang terkoordinir untuk memberikan kepuasan konsumen, sehingga tujuan perusahaan dapat direalisir.

c. Kepuasan konsumen (Consumer Satisfaction)

Faktor yang menentukan apakah perusahaan dalam jangka panjang akan mendapatkan laba, ialah banyak sedikitnya kepuasan konsumen yang dapat terpenuhi.

2. Orientasi Pemasaran pelayanan Kesehatan

Pemasar dalam organisasi pelayanan kesehatan perlu memahami dan membandingkan orientasi-orientasi pemasaran dibawah ini ketika ingin melakukan kegiatan pemasaran ( Irene, 2010:9-11), yaitu :

a. Orientasi Produksi

Suatu orientasi produksi pelayanan kesehatan bahwa tugas utama suatu organisasi adalah mengejar efisiensi dalam produksi dan distribusi.

b. Orientasi Produk

Suatu orientasi produk mempertahankan bahwa tugas utama suatu organisasi adalah menyampaikan produk yang menurutnya mungkin akan baik bagi pasar tersebut.

c. Orientasi Penjualan

Suatu orientasi penjualan memberlakukan bahwa tugas utama suatu organisasi adalah merangsang minat konsumen potensial pada produk-produk dan jasa-jasa yang dimiliki organisasi itu.

d. Orintasi Pemasaran

Suatu orientasi pemasaran memberlakukan bahwa tugas utama suatu organisasi salah menentukan kebutuhan dan keinginan dari pasar target dan memuaskan mereka melalui desain, komunikasi, penentuan harga dan penyampaian yang tepat dan secara kompetitif dari produk-produk dan jasa-jasa layanan menjadi baik.

e. Orintasi Pemasaran Sosial 
Suatu orintasi pemasaran sosial memberlakukan bahwa tugas organisasi adalah menentukan berbagai kebutuhan, keinginan dan kepentingan pasar target dan menyesuaikan orientasi pada penyampaian pemuas-pemuas menjaga dan mempertinggi kesejahtraan konsumen dan masyarakat.

\section{Pelayanan Kesehatan}

Pelayanan kesehatan menurut Levey dan Loomba dalam (Azwar, 2010:42) dalam bukunya pengantar administrasi kesehatan, pelayanan kesehatan adalah setiap upaya yang akan meningkatkan kesehatan, mencegah dan menyembuhkan penyakit serta memulihkan kesehatan perseorangan, keluarga, kelompok dan masyarakat. Pelayanan kesehatan dibagi menjadi dua yaitu pelayanan kedokteran dan pelayanan kesehatan masyarakat.

Sekalipun pelayanan kedokteran berbeda dengan pelayanan kesehatan masyarakat, namun untuk dapat disebut sebagai pelayanan kesehatan yang baik, keduanya harus memiliki berbagai persaratan pokok (Azwar, 2010;45-46). Syarat pokok yang dimaksud adalah :
a. Tersedia dan berkesinambungan
b. Dapat diterima dan wajar
c. Mudah dicapai
d. Mudah Dijangkau
e. Bermutu

D. Perilaku Konsumen

Perilaku konsumen atau (consumer behavior) didefinisikan sebagai kegiatankegiatan individu yang secara langsung terlibat dalam mendapatkan dan mempergunakan barang-barang dan jasajasa, termasuk di dalamnya proses pengambilan keputusan pada persiapan dan penentuan kegiatan-kegiatan tersebut (Swastha Basu, 2012:10).

Keputusan pembelian dari pembeli sangat dipengaruhi oleh faktor kebudayaan, sosial, pribadi dan psikologi dari konsumen. Sebagian besar adalah faktor-faktor yang tidak dapat dikendalikan oleh pemasar.Faktor-faktor yangberpengaruh pada perilaku konsumen (Irine, 2010:86-96) :

a. Faktor Budaya

1) Budaya

Budaya merupakan penentu perilaku yang paling mendasar. Misalnya anak-anak mendapatkan kumpulan nilai, persepsi preferensi dan perilaku dari keluarganya serta lembagalembaga penting lainnya.

2) Sub-budaya

$$
\text { Masing-masing budaya }
$$
terdiri dari sub-budaya yang lebih kecil yang memberikan lebih banyak ciri-ciri dan sosialisasi khusus bagi anggota-anggotanya.

3) Kelas sosial 


Kelas sosial adalah
pembagian masyarakat yang
relatif homogen dan permanen
yang tersusun secara hirarkis dan
anggotanya yang menganut nilai-
nilai, minat dan perilaku yang
serupa.

b. Faktor Sosial

1) Kelompok acuan

$$
\text { Perilaku }
$$

seseorang dipengaruhi oleh banyak kelompok kecil. Ada yang disebut kelompok primer yaitu dimana anggotanya berinteraksi secara tidak formal (keluarga, teman dan sebagainya). Dan kelompok sekunder yaitu dimana seseorang berinteraksi secara formal tetapi tidak reguler (organisasi).

2) Keluarga

Anggota keluarga pembeli dapat memberikan pengaruh yang kuat terhadap perilaku pembeli. Keluarga orientasi adalah keluarga yang terdiri dari orang tua yang memberikan arah dalam hal tuntutan agama, politik, ekonomi dan harga diri.

3) Peran dan status

$$
\text { Posisi seseorang dalam }
$$
kelompok dapat ditentukan dari segi peran dan status. Tiap peran membawa peran yang mencerminkan penghargaan umum oleh keluarga. c. Faktor Pribadi

1) Usia dan tahap siklus hidup

Orang membeli barang dan jasa berbeda sepanjang hidupnya. Mereka makan makanan bayi selama tahun-tahun awal hidupnya, banyak ragam makanan selama tahun pertumbuhan dan kedewasaan, serta diet khusus selama tahun berikutnya. Selera orang terhadap pakaian, perabot dan rekreasi juga berhubungan dengan usia. Konsumsi juga dibentuk oleh siklus hidup keluarga.

2) Pekerjaan dan lingkungan ekonomi

Pekerjaan seseorang juga mempengaruhi pola konsumsinya. Dengan demikian pasar dapat mengidentifikasi kelompok yang berhubungan dengan jabatan yang mempunyai minat di atas ratarata.

3) Gaya hidup

Gaya hidup adalah pola hidup seseorang di dunia yang diekspresikan dalam aktivitas, minat dan opininya. Gaya hidup mengambarkan keseluruhan diri seseorang yang berinteraksi dengan lingkungannya.

4) Kepribadian

Tiap orang mempunyai kepribadian yang khas dan ini 
akan mempengaruhi perilaku pembelinya. Kepribadian sangat bermanfaat untuk menganalisis perilaku konsumen bagi beberapa pilihan produk atau merk.

d. Faktor Psikologis

1) Motivasi

Kebanyakan dari kebutuhankebutuhan yang ada tidak cukup kuat untuk memotivasi seseorang untuk bertindak pada seseorang untuk bertindak pada suatu saat tertentu. Suatu kebutuhan akan berubah menjadi motif apabila kebutuhan yang cukup menekan seseorang untuk mengejar kepuasan.

2) Persepsi

Persepsi yaitu proses individu memilih, merumuskan dan menafsirkan masukan informasi untuk menciptakan suatu gambaran yang berarti mengenai dunia.

3) Pembelajaran

Pembelajaran meliputi perubahan perilaku seseorang yang timbul dari pengalaman. Sebagian besar perilaku manusia adalah hasil proses belajar.

4) Keyakinan dan sikap

Melalui tindakan dan proses belajar orang akan mendapatkan keyakinan dan sikap yang kemudian memepengaruhi perilaku pembeli. Kepercayaan dapat berupa penegetahuan pengetahuan, pendapat atau sekedar percaya.

E. Pelayanan

Suatu jasa pelayanan atau service adalah setiap kegiatan atau keuntungan yang dapat ditawarkan oleh suatu pihak ke pihak lain yang secara essential tidak nampak (intangible) atau tidak menimbulkan kepemilikan sesuatupun (Irine, 2010: 46-47). Sifat layanan yaitu :

a. Sifat tidak nampak (intangible)

Layanan mempunyai sifat tidak nampak, tidak dapat dilihat, dirasakan, diraba, didengar,dicium, sebelum diproduksi.

b. Sifat tidak dapat dipisahkan (inseparability)

Suatu layanan tidak dapat dipisahkan dari sumber yang memberi pelayanan.

c. Sifat tidak tahan lama (perisbability) Suatu Layanan tidak dapat disimpan. Apakah suatu perusahaan jasa berkuaitas, biasabiasa saja atau cukup atau tidak bermutu tergantung pada penilaian pelanggan.

\section{METODE PENELITIAN}

A. Obyek Penelitian 
Penelitian ini dilakukan di Balai

Pengobatan PPKR BSMI jalan Stasiun Prambanan No 5 Kecamatan Prambanan Klaten. Yang menjadi obyek penelitian ini adalah pasien rawat jalan yang menggunakan jasa pelayanan kesehatan di Balai Pengobatan PPKR BSMI Prambanan Klaten.

B. Populasi dan Sampel

a. Populasi

$$
\text { Populasi adalah wilayah }
$$

generalisasi yang terdiri atas: obyek atau subyek yang mempunyai kualitas dan karakteristik tertentu yang di tetapkan oleh peneliti untuk dipelajari dan kemudian ditarik kesimpulannya (Sugiyono, 2011:80). Populasi dalam penelitian ini adalah seluruh pasien rawat jalan yang menggunakan jasa pelayanan kesehatan di Balai Pengobatan Pusat Pelayanan Kesehatan Dan Rehabilitasi (PPKR) BSMI Prambanan Klaten dengan jumlah 175 pasien / minggu.

b. Sampel Penelitian

Sampel adalah bagian dari jumlah dan karakteristik yang dimiliki oleh populasi. Bila populasi besar dan peneliti tidak mungkin mempelajari semua yang ada pada populasi, misalnya karena keterbatasan dana, tenaga, waktu, maka peneliti dapat menggunakan dari populasi itu. Apa yang dipelajari dari sampel, kesimpulannya akan dapat diberlakukan untuk populasi. Untuk itu sampel yang diambil dari populasi harus betul-betulrepresentatif

(mewakili)

(Sugiyono, 2011:81).

Adapun sampelnya adalah pasien rawat jalan yang menggunakan jasa pelayanan kesehatan di Balai Pengobatan Pusat Pelayanan Kesehatan Dan Rehabilitasi (PPKR) BSMI Prambanan Klaten.

Dalam penelitian ini diberlakukan tingkat kesalahan sebesar 10\% dengan catatan sampel tersebut harus representatif atau mewakili populasi. Berdasarkan pertimbangan tersebut, untuk menentukan jumlah sampel yang akan diteliti dengan menggunakan rumus formula solvin.

\section{Metode Pengumpulan Data}

Dalam penelitian ini, metode pengumpulan data yang digunakan adalah studi lapangan. Studi lapangan merupakan suatu pengumpulan data secara langsung terhadap obyek penelitian dengan cara :

\section{a. Data Primer}

Data primer adalah data yang diperoleh langsung dari subjek penelitian dengan mengenakan alat pengukuran atau alat pengambilan data langsung pada subyek sebagai sumber informasi yang dicari(Azwar, 2007:91).

1) Interview (wawancara) 
Wawancara digunakan sebagai teknik pengumpulan data apabila peneliti ingin melakukan studi pendahuluan untuk menemukan permasalahan yang harus diteliti, dan juga apabila peneliti ingin mengetahui hal-hal dari responden yang lebih mendalam dan jumlah respondennya sedikit atau kecil (Sugiyono, 2011:137).

2) Kuesioner (angket)

Kuesioner merupakan teknik pengumpulan data yang dilakukan dengan cara memberi seperangkat pertanyaan atau pernyataan tertulis kepada responden untuk dijawab. Kuesioner merupakan teknik pengumpulan data yang efisien bila peneliti tahu dengan pasti apa variabel yang akan diukur dan tahu apa yang diharapkan responden (Sugiyono, 2011:142).

3) Observasi

Observasi sebagai teknik pengumpulan data mempuyai ciri yang spesifik bila dibandingkan dengan teknik yang lain, yaitu wawancara dan kuesioner. Teknik pengumpulan data dengan observasi digunakan bila, penelitian berkenaan dengan perilaku manusia, proses kerja, gejala-gejala alam dan bila responden yang diamati tidak terlalu besar (Sugiyono, 2011:145). b. Data Sekunder

Data sekunder merupakan sumber data penelitian yang diperoleh peneliti secara tidak langsung melalui media perantara (di peroleh dan di catat oleh pihak lain). Data sekunder umumnya berupa bukti, catatan atau laporan historis yang telah tersusun dalam arsip (data dokumenter) yang dipublikasikan dan yang tidak dipublikasikan (Indriarto dan Supomo,2002:147). Sumber data sekunder dalam penelitian ini adalah :

\section{Studi Kepustakaan}

Studi kepustakaan dilakukan dengan mengumpulkan data dengan cara mempelajari, membahas atau menganalisa suatu masalah yang terdapat di bukubuku karya ilmiah yang berkaitan dengan masalah yang diteliti.

\section{HASIL DAN PEMBAHASAN}

A. Karakteristik Responden

Berdasarkan jenis kelamin, Dari 64 responden yang diteliti, diketahui terdapat 22 orang atau sebesar $34.4 \%$ responden berjenis kelamin pria dan 42 orang atau sebesar $65.6 \%$ responden berjenis kelamin wanita. Jadi, mayoritas pasien Balai Pengobatan dan Pusat Rehabilitasi (PPKR) BSMI Prambanan Klaten yang menjadi responden berdasarkan jenis kelamin sebanyak 42 
orang atau sebesar $65.6 \%$ adalah berjenis kelamin wanita.

Berdasarkan usia, dari 64 responden yang diteliti, diketahui terdapat 6 orang atau sebesar 9.4\% responden berusia kurang dari 20 tahun, 20 orang atau sebesar $31.3 \%$ responden berusia 21-30 tahun, 19 orang atau sebesar $29.7 \%$ responden berusia 31-40 tahun, 6 orang atau sebesar $9.4 \%$ responden berusia 41-50 tahun, dan 13 orang atau sebesar 20.3\% responden berusia > 50 tahun. Jadi, dapat disimpulkan bahwa responden pasien Balai Pengobatan dan Pusat Rehabilitasi (PPKR) BSMI Prambanan Klaten berdasarkan usia, responden terbanyak pada usia antara 2130 tahun dengan jumlah 20 orang atau sebesar $31.3 \%$, dan responden terendah terdapat pada responden yang berusia kurang dari 20 tahun dan responden yang berusia 31-40 tahun yang masing-masing berjumlah 6 orang atau sebesar $9.4 \%$.

Berdasarkan pendidikan terakhir, dari 64 responden yang diteliti, diketahui terdapat 5 orang atau sebesar $7.8 \%$ responden berpendidikan SD, 9 orang atau sebesar $14.1 \%$ responden berpendidikan SLTP, 31 orang atau sebesar $48.4 \%$ responden berpendidikan SLTA, 8 orang atau sebesar $12.5 \%$ responden berpendidikan Diploma, 10 orang atau sebesar $15.6 \%$ responden berpendidikan Strata 1 (S-1) dan 1 orang atau sebesar $1.6 \%$ responden berpendidikan Strata 2 (S-2). Jadi, dapat disimpulkan bahwa pasien Balai Pengobatan dan Pusat Rehabilitasi (PPKR) BSMI Prambanan Klaten yang menjadi responden berdasarkan pendidikan terakhir, responden terbanyak memiliki pendidikan terakhir SLTA dengan jumlah 31 orang atau sebesar $48.4 \%$ dan responden terendah memiliki pendidikan Strata 2 (S2) dengan jumlah 1 orang atau sebesar $1.6 \%$.

Berdasarkan pekerjaan, dari 64 responden yang diteliti, diketahui terdapat 3 orang atau sebesar $4.7 \%$ responden bekerja sebagai PNS, 14 orang atau sebesar $21.9 \%$ responden bekerja sebagai pegawai swasta, responden yang bekerja sebagai TNI/Polisi tidak ada atau sebesar $0 \%$, 20 orang atau sebesar $31.3 \%$ responden bekerja sebagai wiraswasta, 4 orang atau sebesar $6.3 \%$ responden merupakan pelajar/mahasiswa, 5 orang atau sebesar $7.8 \%$ responden merupakan pensiunan dan 18 orang atau sebesar $28.1 \%$ tidak bekerja. Jadi, dapat disimpulkan bahwa pasien Balai Pengobatan dan Pusat Rehabilitasi (PPKR) BSMI Prambanan Klaten yang menjadi responden berdasarkan pekerjaan, responden terbanyak memiliki pekerjaan sebagai wiraswasta dengan jumlah 31 orang atau sebesar $48.4 \%$, dan responden terendah memiliki pekerjaan sebagai TNI/Polisi sebanyak 0 atau sebesar $0 \%$. 
Berdasarkan pendapatan, dari 64 responden yang diteliti, diketahui terdapat 24 orang atau sebesar 37.5\% responden berpendapatan kurang dari $\mathrm{Rp}$ 500.000 perbulan, 18 orang atau sebesar $28.1 \%$ responden berpendapatan $\mathrm{Rp}$ 600.000-1.000.000 perbulan, 4 orang atau sebesar $6.3 \%$ responden berpendapatan Rp 1.100.000-1.500.000 perbulan. 5 orang atau sebesar $7.8 \%$ responden berpendapatan $\mathrm{Rp} \quad 1.600 .000-2.000 .000$ perbulan, dan 13 orang atau sebesar 20.3\% responden berpendapatan lebih dari $\mathrm{Rp}$ 2.000.000-perbulan. Jadi, dapat di simpulkan bahwa pasien Balai Pengobatan dan Pusat Rehabilitasi (PPKR) BSMI Prambanan Klaten yang menjadi responden berdasarkan pendapatan, responden terbanyak memiliki pendapatan sebesar kurang dari Rp 500.000 perbulan dengan jumlah 24 orang atau sebesar $37.5 \%$, dan responden terendah memiliki pendapatan $\mathrm{Rp}$ 1.100.000-1.500.000 perbulan sebanyak 4 orang atau sebesar $6.3 \%$.

\section{A. Uji Hipotesis}

1. Analisis Deskriptif

a. Tingkat Keyakinan Pasien Tentang Jasa Pelayanan $\left(b_{i}\right)$

Tingkat keyakinan pasien tentang jasa pelayanan Balai Pengobatan Pusat Pelayanan Kesehatan Dan Rehabiitasi (PPKR) BSMI Prambanan Klaten dengan atribut pelayanan, tenaga kerja, fasilitas dan lokasi

1) Pelayanan

Tabel tersebut menunjukan bahwa responden mempunyai tingkat keyakinan berdasarkan atribut pelayanan, sebagian besar menyatakan yakin. Hal ini dibuktikan dengan jumlah jawaban yakin sebanyak 182 atau sebesar $(56,88 \%)$, jumlah jawaban sangat yakin sebanyak 73 atau sebesar $(22,81 \%)$, jumlah jawaban cukup yakin sebanyak 63 atau sebesar $(19,69 \%)$, jumlah jawaban tidak yakin sebanyak 2 atau sebesar $(0,62 \%)$, dan jumlah jawaban sangat tidak yakin sebanyak 0 responden $(0,00 \%)$. Dapat disimpulkan bahwa pilihan jawaban responden terbanyak terletak pada jawaban yakin sebanyak 182 atau sebesar $(56,88 \%)$ dan pilihan jawaban terendah terletak pada jawaban sangat tidak yakin sebanyak 0 atau sebesar $(0,00 \%)$.

2) Tenaga Kerja

Tabel tersebut menunjukan bahwa responden mempunyai keyakinan berdasarkan atribut tenaga kerja, sebagian besar menyatakan yakin. Hal ini dibuktikan dengan jumlah jawaban yakin sebanyak 180 atau sebesar 
$(56,25 \%)$, jumlah jawaban sangat yakin sebanyak 104 atau sebesar $(32,50 \% \%)$, jumlah jawaban cukup yakin sebanyak 36 atau sebesar $(10,94 \%)$, jumlah jawaban tidak yakin sebanyak 1 atau sebesar $(0,31 \%)$ dan jumlah jawaban sangat tidak yakin sebanyak 0 atau sebesar $(0,00 \%)$. Dapat disimpulkan bahwa pilihan jawaban responden terbanyak terletak pada jawaban yakin sebanyak 180 atau $(56,25 \%)$ dan pilihan jawaban terendah terletak pada jawaban sangat tidak yakin sebanyak 0 atau sebesar $(0,00 \%)$.

3) Fasilitas

Tabel tersebut menunjukan bahwa responden mempunyai keyakinan berdasarkan atribut fasilitas, sebagian besar menyatakan yakin. Hal ini dibuktikan dengan jumlah jawaban yakin sebanyak 150 atau sebesar $(46,87 \%)$, jumlah jawaban cukup yakin sebanyak 113 atau sebesar (35,31\%), jumlah jawaban sangat yakin sebanyak 47 atau sebesar (14,69\%), jumlah jawaban tidak yakin sebanyak 2 atau sebesar $(3,13 \%)$ dan jumlah jawaban sangat tidak yakin sebanyak 0 atau sebesar $(0,00 \%)$. Dapat disimpulkan bahwa pilihan jawaban responden terbanyak terletak pada jawaban yakin sebanyak 150 atau sebesar $(46,87 \%)$ dan pilihan jawaban terendah terletak pada jawaban sangat tidak yakin sebanyak 0 atau sebesar $(0,00 \%)$.

4) Lokasi

Tabel tersebut menunjukan bahwa responden mempunyai keyakinan berdasarkan atribut lokasi, sebagian besar menyatakan yakin. Hal ini dibuktikan dengan jumlah jawaban yakin sebanyak 164 atau sebesar (51,25\%), jumlah jawaban sangat yakin sebanyak 105 atau sebesar (32,81\%), jumlah jawaban cukup yakin sebanyak 46 atau sebesar (14,38\%), jumlah jawaban tidak yakin sebanyak 15 atau sebesar (1,56\%) dan jumlah jawaban sangat tidak yakin sebanyak 0 atau sebesar $(0,00 \%)$. Dapat di simpulkan bahwa pilihan jawaban responden terbanyak terletak pada jawaban yakin sebanyak 164 atau sebesar (51,25\%) dan pilihan jawaban terendah terletak pada jawaban sangat tidak yakin sebanyak 0 atau sebesar responden $(0,00 \%)$.

b. Tingkat Penilaian Pasien

Tentang Jasa Pelayanan $\left(\mathrm{e}_{\mathrm{i}}\right)$

Tingkat penilaian pasien tentang jasa Pelayanan Kesehatan Dan Rehabilitasi (PPKR atribut pelayanan, tenaga kerja, fasilitas dan lokí 
1) Pelayanan

Tabel tersebut menunjukkan bahwa responden mempunyai penilaian berdasarkan atribut tenaga kerja, sebagian besar menyatakan puas. Hal ini dibuktikan dengan jumlah jawaban puas sebanyak 187 atau sebesar (58,44\%), jumlah jawaban cukup puas sebanyak 67 atau sebesar (20,94\%), jumlah jawaban sangat puas sebanyak 64 atau sebesar (20,00\%), jumlah jawaban tidak puas sebanyak 3 atau sebesar $(0,62 \%)$ dan jumlah jawaban sangat tidak puas sebanyak 0 atau sebesar $(0,00 \%)$. Dapat disimpulkan bahwa pilihan jawaban responden terbanyak terletak pada jawaban puas sebanyak 187 atau sebesar $(58,44 \%)$ dan pilihan jawaban terendah terletak pada jawaban sangat tidak puas sebanyak 0 atau sebesar $(0,00 \%)$

\section{2) Tenaga Kerja}

Tabel tersebut menunjukkan bahwa responden mempunyai penilaian berdasarkan atribut tenaga kerja, sebagian besar menyatakan puas. Hal ini dibuktikan dengan jumlah jawaban puas sebanyak 179 atau sebesar (55,94\%), jumlah jawaban sangat puas sebanyak 101 atau sebesar (31,56\%), jumlah jawaban cukup puas sebanyak 37 atau sebesar (11,56\%), jumlah jawaban tidak puas sebanyak 3 atau sebesar $(0,94 \%)$ dan jumlah jawaban sangat tidak puas sebanyak 0 atau sebesar (0,00\%). Dapat disimpulkan bahwa pilihan jawaban responden terbanyak terletak pada jawaban puas sebanyak 179 atau sebesar $(55,94 \%)$ dan pilihan jawaban terendah terletak pada jawaban sangat tidak puas sebanyak 0 atau sebesar $(0,00 \%)$.

3) Fasilitas

Tabel tersebut menunjukan bahwa responden mempunyai penilaian berdasarkan atribut tenaga kerja, sebagian besar menyatakan puas. Hal ini dibuktikan dengan jumlah jawaban puas sebanyak 147 atau sebesar (45,94\%), jumlah jawaban cukup puas sebanyak 113 atau sebesar (35,31\%), jumlah jawaban sangat puas sebanyak 44 atau sebesar (13,75\%), jumlah jawaban tidak puas sebanyak 15 atau sebesar (4,69\%) dan jumlah jawaban sangat tidak puas sebanyak 1 atau sebesar (0,31\%). Dapat disimpulkan bahwa pilihan jawaban responden terbanyak terletak pada jawaban puas sebanyak 147 atau sebesar $(45,94 \%)$ dan pilihan jawaban terendah terletak pada 
jawaban sangat tidak puas sebanyak

1 atau sebesar $(0,31 \%)$.

4) Lokasi

Tabel tersebut menunjukan bahwa responden mempunyai penilaian berdasarkan atribut tenaga kerja, sebagian besar menyatakan puas. Hal ini dibuktikan dengan jumlah jawaban puas sebanyak 148 atau sebesar $(46,25 \%)$, jumlah jawaban sangat puas sebanyak 112 atau sebesar (35.00\%), jumlah jawaban cukup puas sebanyak 53 atau sebesar (16,56\%), jumlah jawaban tidak puas sebanyak 6 atau sebesar $(1,88 \%)$ dan jumlah jawaban sangat tidak puas sebanyak 1 atau sebesar $(0,31 \%)$. Dapat disimpulkan bahwa pilihan jawaban responden terbanyak terletak pada jawaban puas sebanyak 148 atau sebesar $(46,25 \%)$ dan pilihan jawaban terendah terletak pada jawaban sangat tidak puas sebanyak 1 atau sebesar $(0,31 \%)$.

\section{Analisis Indeks Sikap}

Analisis ini digunakan untuk mengetahui sikap penilaian individu terhadap suatu obyek atau produk. Penilaian yang akan dianalisis adalah sikap penilaian pasien tentang jasa pelayanan kesehatan di Balai Pengobatan Pusat $\begin{array}{lcr}\text { Pelayanan } & \text { Kesehatan } & \text { dan } \\ \text { Rehabilitasi } & \text { (PPKR) } & \text { BSMI }\end{array}$ Prambanan Klaten yang meliputi atribut pelayanan, tenaga kerja, fasilitas dan lokasi pada penelitian ini menggunakan model Fishbein.

Analisis yang terkandung dalam rumus model Fishbein adalah variabel keyakinan $\left(b_{i}\right)$ dan evaluasi $\left(\mathrm{e}_{\mathrm{i}}\right)$. Dengan demikian analisis Fishbein dapat digunakan dalam menganalisis keyakinan $\left(b_{i}\right)$ dan evaluasi $\left(e_{i}\right)$ jasa pelayanan kesehatan dengan cara menganalisis nilai antara keyakinan $\left(b_{i}\right)$ dengan evaluasi ( $\left.e_{i}\right)$ kemudian hasilnya dipadukan dengan skor maksimum sikap konsumen tentang skala pengukuran atau penilaian, di mana skor maksimum sikap konsumen dapat dicari dengan cara mengalikan bobot pengukuran dan keyakinan $\left(e_{i}\right)$, karena keyakinan $\left(b_{i}\right)$ dan evaluasi $\left(\mathrm{e}_{\mathrm{i}}\right)$ merupakan variabel yang berbeda, maka harus dicari secara terpisah.

Perhitungan antara penilaian keyakinan $\left(b_{i}\right)$ dan penilaian $\left(e_{i}\right)$ dalam pengukuran sikap konsumen, yaitu sebagai berikut :

a. Tingkat Keyakinan Pasien

Tentang Jasa Kesehatan $\left(b_{i}\right)$

Hasil perhitungan tingkat keyakinan pasien tentang jasa pelayanan kesehatan yang 
meliputi atribut pelayanan, atribut tenaga kerja, atribut fasilitas dan atribut lokasi di Balai Pengobatan Pusat Pelayanan Kesehatan dan Rehabilitasi PPKR BSMI Prambanan Klaten dapat di lihat dalam tabel 4.7 sebagai berikut :

TABEL 1.1HASIL PERHITUNGAN TINGKAT KEYAKINAN PASIEN TENTANG JASA PELAYANAN KESEHATAN

\begin{tabular}{lccccccc}
\hline & \multicolumn{7}{c}{ Alternatif Jawaban } \\
\multicolumn{1}{c}{ Atribut } & SY & Y & CY & TY & STY & Jumlah & Tertimt \\
& 5 & 4 & 3 & 2 & 1 & & Rata-ra \\
\hline Pelayanan & 14,60 & 36,40 & 12,60 & 0,40 & 0,00 & 257,2 & 4,02 \\
Tenaga Kerja & 20,80 & 36,00 & 7,00 & 0,20 & 0,00 & 269,4 & 4,21 \\
Fasilitas & 9,40 & 30,00 & 22,60 & 2,00 & 0,00 & 238,8 & 3,73 \\
Lokasi & 21,00 & 32,80 & 9,20 & 1,00 & 0,00 & 265,8 & 4,15 \\
\hline
\end{tabular}

Rata-rata tertimbang untuk atributatribut pada tingkat keyakinan pasien tentang jasa pelayanan di Balai Pengobatan Pusat Pelayanan Kesehatan dan Rehabilitasi (PPKR) BSMI Prambanan Klaten diperoleh dengan cara sebagai berikut :

1) Pelayanan

$\frac{(14,801 \times 5)+(36,40 \times 4)+(12,60 \times 3)-(0,40 \times 2)+(0,00 \times 1)}{64}=\frac{257,2}{64}=4,02$

2) Tenaga Kerja

$\frac{(20,80 \times 5)-(36,00 \times 4)-(7,00 \times 3)-(0,20 \times 2)-(0,00 \times 1)}{64}=\frac{269,4}{64}=4,21$

3) Fasilitas

$\frac{(2,40 \times 5)+(30,00 \times 4)-(22,60 \times 3)+(2,00 \times 2)-(0,00 \times 1)}{64}=\frac{238,8}{64}=3,73$
4) Lokasi

$\frac{(21,00 \times 5)+(32,80 \times 4)+(9,20 \times 3)+(1,00 \times 2)+(0,00 \times 1)}{64}=\frac{265,8}{64}=4,13$

Berdasarkan hasil perhitungan tingkat keyakinan pasien tentang jasa pelayanan kesehatan di Balai Pengobatan Pusat Pelayanan Kesehatan dan Rehabilitasi (PPKR) BSMI Prambanan Klaten di dapat hasil bahwa atribut tenaga kerja merupakan tingkat keyakinan pasien yang tertinggi dengan rata-rata tertimbang sebesar 4,21, atribut lokasi berada pada urutan kedua dengan tingkat keyakinan pasien rata-rata tertimbang sebesar 4,15, atribut pelayanan berada pada urutan ketiga dengan tingkat keyakinan rata-rata tertimbang sebesar 4,02 dan atribut fasilitas merupakan yang terendah dengan rata-rata tertimbang sebesar 3,75.

b. Tingkat Penilaian Pasien Tentang Jasa Kesehatan $\left(b_{i}\right)$

Hasil perhitungan tingkat penilaian pasien tentang jasa pelayanan kesehatan yang meliputi atribut pelayanan, atribut tenaga kerja, atribut fasilitas dan atribut lokasi di Balai Pengobatan Pusat Pelayanan Kesehatan dan Rehabilitasi PPKR BSMI Prambanan Klaten dapat di lihat dalam tabel 4.8 sebagai berikut :

TABEL 1.2HASIL PERHITUNGAN TINGKAT PENILAIAN PASIEN 
TENTANG JASA PELAYANAN KESEHATAN

\begin{tabular}{cccccccc}
\hline \multicolumn{8}{c}{ Alternatif Jawaban } \\
Atribut & $S Y$ & $Y$ & CY & TY & STY & Jumlah & $\begin{array}{c}\text { Rata-rata } \\
\text { Tertimbang }\end{array}$ \\
& 5 & 4 & 3 & 2 & 1 & & \\
\hline Pelayanan & 12,80 & 37,40 & 13,40 & 1,40 & 0,00 & 254,6 & 3,97 \\
Tenaga & 20,20 & 35,80 & 7,40 & 0,60 & 0,00 & 266,3 & 4,16 \\
Kerja & & & & & & 3,68 \\
Fasilitas & 8,80 & 29,40 & 22,60 & 3,00 & 1,20 & 235,6 & 3,13 \\
Lokasi & 22,40 & 29,60 & 10,60 & 1,20 & 0,20 & 264,8 & 4 \\
\hline
\end{tabular}

Rata-rata tertimbang untuk atribut-atribut pada tingkat keyakinan pasien tentang jasa pelayanan di Balai Pengobatan Pusat Pelayanan Kesehatan dan Rehabilitasi (PPKR) BSMI Prambanan Klaten diperoleh dengan cara sebagai berikut :

1) Pelayanan $\frac{(12,80 \times 5)+(37,40 \times 4)+(13,40 \times 3)+(0,40 \times 2)+(0,00 \times 1)}{64}=\frac{254,6}{64}=3,97$

2) Tenaga Kerja $\frac{(20,00 \times 5)+(35,80 \times 4)+(7,40 \times 3)+(0,60 \times 2)+(0,00 \times 1)}{64}=\frac{266,3}{64}=4,16$

3) Fasilitas $\frac{(8,80 \times 5)+(29,40 \times 4)+(22,60 \times 3)+(3,00 \times 2)+(0,20 \times 1)}{64}=\frac{235,6}{64}=3,68$

4) Lokasi

$\frac{(22,40 \times 5)+(29,60 \times 4)+(10,60 \times 3)+(1,20 \times 2)+(0,20 \times 1)}{64}=\frac{264,8}{64}=4,13$

Berdasarkan hasil perhitungan tingkat penilaian pasien tentang jasa pelayanan kesehatan di Balai Pengobatan Pusat Pelayanan Kesehatan dan Rehabilitasi (PPKR) BSMI Prambanan Klaten di dapat hasil bahwa atribut tenaga kerja merupakan tingkat penilaian pasien yang tertinggi dengan rata-rata tertimbang sebesar 4,16, atribut lokasi berada pada urutan kedua dengan tingkat penilaian pasien rata-rata tertimbang sebesar 4,13, atribut pelayanan berada pada urutan ketiga dengan tingkat keyakinan rata-rata tertimbang sebesar 3,97 dan atribut fasilitas merupakan yang terendah dengan rata-rata tertimbang sebesar 3,68.

Setelah diperoleh rata-rata tertimbang dari masing-masing atribut, langkah selanjutnya adalah mencari nilai sikap secara keseluruhan tentang atribut pelayanan, tenaga kerja, fasilitas dan lokasi yang akan di terangkan dalam tabel 4.9 sebagai berikut :

TABEL 1.3NILAI SIKAP PASIEN TENTANG JASA PELAYANAN KESEHATAN

\begin{tabular}{|c|c|c|c|}
\hline Atribut & $\begin{array}{l}\text { Keyakinan } \\
\text { (bi) }\end{array}$ & $\begin{array}{l}\text { Evaluasi } \\
\text { (ei) }\end{array}$ & $\begin{array}{l}\text { Total Ab= } \\
\text { (bi) }) \times(e i)\end{array}$ \\
\hline Pelayanan & 4,02 & 3,97 & 15,96 \\
\hline $\begin{array}{l}\text { Tenaga } \\
\text { Kerja }\end{array}$ & 4,21 & 4,16 & 17,51 \\
\hline Fasilitas & 3,73 & 3,68 & 13,72 \\
\hline Lokasi & 4,15 & 4,13 & 17,14 \\
\hline Jumlah & & & 64,44 \\
\hline
\end{tabular}

Berdasarkan hasil perhitungan pada tabel di atas tersebut, dapat diketahui bahwa dengan adanya keyakinan $\left(b_{i}\right)$ dan penilaian $\left(\mathrm{e}_{\mathrm{i}}\right)$ konsumen tentang jasa pelayanan kesehatan di Balai Pengobatan Pusat Pelayanan Kesehatan dan Rehabilitasi (PPKR) BSMI Prambanan Klaten dapat diketahui nilai sikap pasien sebesar 64,44 .

Selanjutnya untuk mengetahui sikap konsumen bernilai 64,44 berada pada interval mana, maka perlu 
menghitung skor maksimum untuk sikap. Adapun skor maksimum untuk sikap dapat dilihat pada tabel 4.10 berikut ini :

TABEL 1.4SKOR MAKSIMUM UNTUK SIKAP PASIEN

\begin{tabular}{|c|c|c|c|}
\hline Atribut & $\begin{array}{l}\text { Penilaian } \\
\text { ideal }\end{array}$ & $\begin{array}{c}\text { Keyaki } \\
\text { nan } \\
\text { (bi) }\end{array}$ & Total \\
\hline Pelayanan & 5 & 4,02 & 20,10 \\
\hline Tenaga & & \multirow{2}{*}{4,21} & \\
\hline Kerja & 5 & & 21,05 \\
\hline Fasilitas & 5 & \multirow{3}{*}{$\begin{array}{l}3,73 \\
4,15\end{array}$} & 18,65 \\
\hline Lokasi & 5 & & 20,75 \\
\hline & Jumlah & & 80,55 \\
\hline
\end{tabular}

Setelah diketahui skor maksimum mengenai sikap pasien tentang jasa pelayanan kesehatan yang meliputi atribut pelayanan, tenaga kerja, fasilitas dan lokasi di Balai Pengobatan Pusat Pelayanan Kesehatan dan Rehabilitasi (PPKR) BSMI Prambanan Klaten, maka langkah selanjutnya adalah menentukan skor minimum sikap dengan car $\mathrm{a} \frac{80,55}{5}=16,11 \quad$ kemudian untuk menentukan interval kelas, skor tertinggi dikurangi skor terendah dibagi kelas sikap $=\frac{80,55-16,11}{5}=12,88$

TABEL 1.5INTERVAL PENILAIAN SIKAP

\begin{tabular}{lc}
\hline \multicolumn{1}{c}{ Sikap } & Interval \\
\hline Sangat Positif & $67,67<x<80,55$ \\
Positif & $54,78<x<67,66$ \\
Cukup Positif & $41,89<x<54,77$ \\
\hline
\end{tabular}

\begin{tabular}{ll}
\hline Negatif & $29,00<x<41,88$ \\
Sangat Negatif & $16,11<x<28,99$ \\
\hline
\end{tabular}

Berdasarkan interval penilaian sikap tersebut, maka hasil penelitian sikap pasien sebesar 64,44 masuk pada interval $54,78<x<67,66$ berarti sikap pasien positif tentang jasa pelayanan kesehatan yang meliputi atribut pelayanan, tenaga kerja, fasilitas dan lokasi di Balai Pengobatan Pusat Pelayanan Kesehatan dan Rehabilitasi (PPKR) BSMI Prambanan Klaten.

Dikatakan positif karena dari penelitian terhadap pasien rawat jalan tentang jasa pelayanan kesehatan yang meliputi atribut pelayanan, tenaga kerja, fasilitas dan lokasi dapat memberikan tingkat keyakinan dan penilaian yang besar. Hasil penelitian tersebut dimasukkan dalam interval penilaian sikap dimana besarnya nilai dari hasil penelitian ini berada pada interval $54,78<x<67,66$ dan interval tersebut berada pada sikap positif.

\section{B. PEMBAHASAN}

Sikap dapat diukur dengan menggunakan attidude towar object model. Model ini digunakan untuk mengidentifikasi bagaimana konsumen merangkai kepercayaan terhadap atribut suatu produk, sehingga membentuk sikap tentang berbagai obyek. Model ini 
mempunyai asumsi bahwa konsumen menggunakan pendekatan stand

ar hirarki efek dimana kepercayaan dapat membentuk suatu sikap. Mengingat model ini digunakan untuk mengetahui sikap konsumen, model ini juga disebut Model Sikap Fishbein. Caranya adalah dengan menghitung nilai sikap (AB) (Rangkuti, 2003: 69)

Berdasarkan hasil perhitungan tingkat keyakinan pasien tentang jasa pelayanan kesehatan di Balai Pengobatan Pusat Pelayanan Kesehatan dan Rehabilitasi (PPKR) BSMI Prambanan Klaten dengan jumlah 64 pasien di dapat hasil bahwa atribut tenaga kerja yang meliputi pernyataan dokter sangat teliti dan akurat dalam memeriksa dan mendiagnosa penyakit, dokter selalu menanggapi dengan sabar apa yang menjadi keluhan dan masalah pasien, dokter tidak membedakan pelayanan pada pasien yang datang ke klinik, kecepatan dokter dalam memberikan pelayanan pengobatan kepada pasien di klinik dan dokter dalam memberikan informasi kepada pasien tentang penyakit maupun pengobatan penyakit tentang penyakit sangat sopan dan ramah yang merupakan tingkat keyakinan pasien yang tertinggi dengan rata-rata tertimbang sebesar 4,21, atribut lokasi yang meliputi pernyataan lingkungan lokasi klinik sangat aman dan nyaman, lokasi klinik mudah dijangkau dan dekat rumah saya, lokasi klinik bebas dikunjungi oleh siapapun untuk berobat, lokasi klinik sangat strategis dan dekat dengan jalan raya, lokasi klinik mudah dijangkau dengan sarana transportasi atau angkutan umum, berada pada urutan kedua dengan tingkat keyakinan pasien rata-rata tertimbang sebesar 4,15 , atribut pelayanan yang meliputi pernyataan lingkungan klinik sangat aman, nyaman dan bersih sehingga pasien merasa sangat nyaman dalam melakukan pemeriksaan, pemeriksaan dan diagnosa sangat capat dan tepat sesuai harapan pasien, pelayanan yang diberikan sangat cepat dalam memberikan pengobatan atau tindakan, tersedianya jenis, jumlah dan kualitas obat yang diterima dalam pelayanan kebutuhan dan kritik ataupun keluhan dari pasien ditanggapai dengan baik oleh petugas, berada pada urutan ketiga dengan tingkat keyakinan rata-rata tertimbang sebesar 4,02 dan atribut fasilitas yang meliputi pernyataan fasilitas dan peralatan medis di klinik sangat lengkap dan memadai, ruang tunggu sangat lengkap dan memadai, klinik menyediakan tempat informasi pendaftaran sehingga pasien mudah dalam mendapatkan pelayanan untuk berobat dan klinik menyediakan tempat parkir yang aman dan nyaman merupakan yang terendah dengan ratarata tertimbang sebesar 3,73. 
Berdasarkan hasil perhitungan tingkat penilaian pasien tentang jasa pelayanan kesehatan di Balai Pengobatan Pusat Pelayanan Kesehatan dan Rehabilitasi (PPKR) BSMI Prambanan Klaten dengan jumlah 64 pasien di dapat hasil bahwa atribut tenaga kerja yang meliputi pernyataan sikap dokter sangat teliti dan akurat dalam memeriksa dan mendiagnosa penyakit, dokter selalu menanggapi dengan sabar apa yang menjadi keluhan dan masalah pasien, dokter tidak membedakan pelayanan pada pasien yang datang ke klinik, kecepatan dokter dalam memberikan pelayanan pengobatan kepada pasien di klinik dan dokter dalam memberikan informasi kepada pasien tentang penyakit maupun pengobatan penyakit tentang penyakit sangat sopan dan ramah yang merupakan tingkat keyakinan pasien yang tertinggi dengan rata-rata tertimbang sebesar 4,16, atribut lokasi yang meliputi pernyataan lingkungan lokasi klinik sangat aman dan nyaman, lokasi klinik mudah dijangkau dan dekat rumah saya, lokasi klinik bebas dikunjungi oleh siapapun untuk berobat, lokasi klinik sangat strategis dan dekat dengan jalan raya, lokasi klinik mudah dijangkau dengan sarana transportasi atau angkutan umum, berada pada urutan kedua dengan tingkat keyakinan pasien rata-rata tertimbang sebesar 4,13, atribut pelayanan yang meliputi pernyataan lingkungan klinik sangat aman, nyaman dan bersih sehingga pasien merasa sangat nyaman dalam melakukan pemeriksaan, pemeriksaan dan diagnosa sangat capat dan tepat sesuai harapan pasien, pelayanan yang diberikan sangat cepat dalam memberikan pengobatan atau tindakan, tersedianya jenis, jumlah dan kualitas obat yang diterima dalam pelayanan kebutuhan dan kritik ataupun keluhan dari pasien ditanggapai dengan baik oleh petugas, berada pada urutan ketiga dengan tingkat keyakinan rata-rata tertimbang sebesar 3,97 dan atribut fasilitas yang meliputi pernyataan fasilitas dan peralatan medis di klinik sangat lengkap dan memadai, ruang tunggu sangat lengkap dan memadai, klinik menyediakan tempat informasi pendaftaran sehingga pasien mudah dalam mendapatkan pelayanan untuk berobat dan klinik menyediakan tempat parkir yang aman dan nyaman merupakan yang terendah dengan ratarata tertimbang sebesar 3,68.

Berdasarkan hasil perhitungan nilai sikap pasien tentang jasa pelayanan kesehatan di Balai Pengobatan Pusat Pelayanan Kesehatan dan Rehabilitasi (PPKR) BSMI Prambanan Klaten diketahui bersifat positif hal tersebut sesuai dengan hipotesis yang berbunyi bahwa sikap pasien tentang jasa pelayanan kesehatan di Balai Pengobatan Pusat Pelayanan Kesehatan dan 
Rehabilitasi (PPKR) BSMI Prambanan Klaten bersikap positif. Menurut Heri Purwanto, kategori sikap terdiri dari : sikap positif, yaitu kecenderungan tindakan untuk mendekati, menyenangi, menghadapkan objek tertentu dan sikap negatif, terdapat kecenderungan untuk menjauhi, menghindari, membenci, tidak menyukai objek tertentu. Karena sikap pasien bersifat positif artinya, berarti pasien cenderung untuk untuk mendekati, menyenangi, dari pelayanan jasa kesehatan yang diberikan oleh Balai Pengobatan Pusat Pelayanan Kesehatan dan Rehabilitasi (PPKR) BSMI Prambanan Klaten.

Hal ini dapat dibuktikan setelah melakukan perhitungan terhadap nilai sikap Total $\mathrm{Ab}=(\mathrm{bi})$ ) $\times$ (ei) dengan atribut pelayanan sebesar 15,96, atribut tenaga kerja dengan nilai sebesar 17,51, atribut fasilitas dengan nilai sebesar 13,72, atribut lokasi dengan nilai sebesar 17,14 dan dengan total keseluruhan dari atribut tersebut dengan nilai 64,44 yang berada pada interval positif yaitu $54,78<x<67,66$.

\section{KESIMPULAN DAN SARAN}

A. Kesimpulan

1. Berdasarkan hasil perhitungan tingkat keyakinan pasien tentang jasa pelayanan kesehatan meliputi atribut pelayanan, tenaga kerja, fasilitas dan lokasi di Balai Pengobatan Pusat Pelayanan Kesehatan dan Rehabilitasi
(PPKR) BSMI Prambanan Klaten di dapat hasil bahwa atribut tenaga kerja merupakan atribut yang mempunyai tingkat keyakinan pasien yang tertinggi dengan rata-rata tertimbang sebesar 4,21 dan atribut fasilitas merupakan atribut yang mempunyai tingkat keyakinan pasien terendah dengan rata-rata tertimbang sebesar 3,73.

2. Berdasarkan hasil perhitungan tingkat penilaian pasien jasa pelayanan kesehatan yang meliputi atribut pelayanan, tenaga kerja, fasilitas dan lokasi di Balai Pengobatan Pusat Pelayanan Kesehatan dan Rehabilitasi (PPKR) BSMI Prambanan Klaten didapat hasil bahwa atribut tenaga kerja merupakan tingkat penilaian pasien merupakan atribut yang mempunyai tingkat penilaian yang tertinggi dengan rata-rata tertimbang sebesar 4,16 dan atribut fasilitas merupakan atribut yang mempunyai yang tingkat penilaian terendah dengan rata-rata tertimbang sebesar 3,68 .

B. Saran

1. Sikap penilaian dan keyakinan pasien tentang jasa pelayanan kesehatan di Balai Pengobatan Pusat Pelayanan Kesehatan dan Rehabilitasi (PPKR) BSMI Prambanan Klaten dapat diketahui bersikap positif, dengan demikian diharapkan pihak Klinik untuk tetap meningkatkan dan 
mempertahankan kualitas jasa pelayanan yang sudah ada atau dengan membuat inovasi baru atau memberikan keunggulan-keunggulan yang lebih baik dan berbeda dari jasa pelayanan kesehatan lainnya, sehingga pasien akan merasa puas dan sepenuhnya dapat mempercayai terhadap kualitas jasa pelayanan kesehatan yang diberikan oleh pihak klinik.

2. Untuk bersaing dengan para penyedia jasa pelayanan kesehatan lainnya, pihak klinik harus selalu mengikuti perkembangan teknologi ataupun suatu program khusus dalam meningkatkan kualitas pelayanan.

\section{DAFTAR PUSTAKA}

Gunawan, Agus, 2008. Analilis Sikap Penilaian Konsumen Terhadap Kualitas Produk Jamu Komplit Sido Muncul di Toko Jamu Seduhan Duta Gedong Kuning Yogyakarta. Skripsi STIE IEU. Yogyakarta.

Indriantoro dan Supomo,2002. Metodologi Penelitian Bisnis, Untuk Akuntansi dan Pemasaranedisi pertama cetakan kedua BPFE Yogyakarta.

Kottler, Philip dan Keller, Kevin Lane, 2009. Manajemen Pemasaran, Jilid 1 Edisi Ketigabelas.Penerbit Erlangga, Cikeas, Jakarta.
Lupiyohadi, Rambat, 2001.Manajemen pemasaran jasa teori dan praktik, Salemba Empat, Jakarta.

Luthfi, Zainul, 2011. Analisis Penilaian Sikap Nasabah Terhadap Pelayanan Dan Produk di BRI Kantor Cabang Cik Dik Tiro Yogyakarta, Skripsi STIE IEU, Yogyakarta.

Sari W. Irine, 2010. Manajemen Pemasaran Usaha Kesehatan Masyarakat Cetakan Keempat, Nuha Medika, Yogyakarta.

Setiadi, Nugroho J, 2010. Prilaku Konsumen Edisi Revisi, Kencana Prenada Media Group, Rawamangun, Jakarta.

Soehardi, Sigit, 2003, Pengantar Metodelogi Penelitian Sosial, Bisnis Manajemen, Cetakan Ketiga, BPFE, Yogjakarta.

Swasta, Basu dan Handoko, Hani, 2012.Manajemen Pemasaran Analisa Prilaku Konsumen, Edisi 1 Cetakan Kelima, Liberty, Yogyakara 
